\section{Virus of Enzootic Abortion in Ewes: Antigenic Relationship with Viruses of the Psittacosis Group}

LARGE numbers of elementary bodies were found by Stamp et al. ${ }^{1}$ in the foetal membranes from sheep after experimental transmission of enzootic abortion in ewes ; these were described as having the morphological and staining properties of a rickettsia or a virus of the psittacosis-lymphogranuloma group. The exact nature of the agent remained uncertain, although later studies ${ }^{2}$ on its development in the chorio-allantoic membrane of fertile eggs suggested that the latter relationship was the more probable. The following experiments were made in order to determine whether the virus of enzootic abortion in ewes has antigenic properties which would define its position from this point of view.

After cultivation in developing hens' eggs, we obtained rich yields of elementary bodies in yolk-sac suspensions which were partially purified by differential centrifugation and heated in a boiling-water bath for twenty minutes.

Using the complement-fixation technique, such a heated suspension was tested against serial dilutions of human sera from cases of psittacosis and lymphogranuloma venereum; standard heated preparations of these last-named viruses were also included. It was found that enzootic abortion virus, at dilutions comparable with those of the other two suspensions, gave a full degree of complement fixation in the presence of both sera.

Further tests showed that the antibody reacting with all three virus preparations could be removed completely from both sera by absorption with a heated suspension of the new virus ${ }^{3}$. Mr. Stamp has also sent us three samples of serum from infected sheep; all of them were found to fix complement to a similar extent with heated preparations of psittacosis and the homologous virus. In each case a serum titre of 1 in 64 was recorded.

The heat-stable antigen common to the psittacosislymphogranuloma viruses is thus readily demonstrated in the virus of enzootic abortion of ewes, which should therefore be classified with this group.

Department of Bacteriology,

$$
\begin{aligned}
& \text { C. F. Barwell } \\
& \text { L. W. J. Bishop }
\end{aligned}
$$

London Hospital Medical College,

London, E.1.

Feb. 8.

' Stamp, J. T., McEwen, A. D., Watt, J. A. A., and Nisbet, D. I., Vet. Rec.,' 62, 251 (1949).

- Stamp, J. T. (personal communication). 'Bedson, S. P., Barwell, C. F., King, E. J., and Bishop, I. W. J.,

\section{Blood Groups of Brazilian Indians}

BLOOD-SAMPLES from 73 pure-bred Brazilian Indians in the interior of the Mato Grosso, Brazil, have been examined by us for the presence of the antigens $A, B, C, c, D, E, e, M, N, S, P$, Lutheran, Kell and Duffy $\left(F y^{a}\right)$. An account of this work will be published elsewhere in full.

The point of special interest is that all these Brazilian Indian bloods were Duffy-negative.

The blood-group antigen Duffy or $F y^{a}$ was discovered by Cutbush, Mollison and Parkin ${ }^{1}$, who found the corresponding antibody in the serum of a man immunized by transfusion. The most complete published figures, those of Race and Sanger ${ }^{2}$, show that $F y^{a}$ is present in the blood of 65 per cent of English people. Cutbush and Mollison ${ }^{3}$ have found it in 91 per cent of people from north-wost Pakistan ; Miller, Rosenfield and Vogel ${ }^{4}$ in 99 per cent of Chinese and in 26 per cent of American Negroes; and Hartmann and Brendemoen ${ }^{5}$ in 97 per cent of Norwegian Lapps. The fact that all Brazilian Indians so far tested should lack this antigen is a fact which may prove to be of considerable anthropological importance.

This work was made possible by the generosity of the Brazilian Government, through the Instituto Oswaldo Cruz, the Brasil Central Foundation, the Serviço do Proteção dos Indios, and the Brazilian Air Force, which provided transport. The extensive local knowledge and the exact personal records made over many years by the Brasil Central Foundation and the Serviço dos Indios assured the racial purity and the genealogy of our subjects.

The anti- $F y^{a}$ serum used was supplied by the kind. ness of Dr. P. L. Mollison. The antibody exists only in the 'incomplete' form and was used by the Coombs anti-human-globulin technique. It gave strong positive reactions with 8 out of 16 white Brazilian controls (Portuguese, English, French and German).

We should like to thank Drs. O. J. Brendemoen, O. Hartmann, E. B. Miller, R. E. Rosenfield and P. Vogel for allowing us to quote their unpublished results.

A. M. Pantin

P. C. JUNQUETRA

Department of Hæmatology,

Instituto Oswaldo Cruz,

Rio de Janeiro. Dec. 11.

1 Cutbush, Marie, Mollison, P. L., and Parkin, Dorothy M., Nature, $165,188(1950)$

${ }^{2}$ Race, R. R., and Sanger, Ruth, "Blood Groups in Man", 206 (Blackwell Scientifle Publications, Oxford, 1950).

${ }^{3}$ Cutbush, Marie, and Mollison, P. I., Heredity, 4, 383 (1950).

5 Miller, E. B., Rosenfleld, R. E., and Vogel, P. (personal communication, 1950).

s Hartmann, O., and Brendemoen, O. J. (personal communication, 1950).

\section{A Serious Sugar-cane Disease in British Guiana}

A SUGAR-CANE disease with internal and external symptoms like 'leaf-scald' (Xanthomonas albilineans) is widespread throughout British Guiana and is causing serious losses. Varieties $B .34104$ and $D .14 / 34$, which account respectively for 70 and 15 per cent of plantings, are affected both as plants and ratoons. Isolations of the causal organism have been made and successfully re-inoculated.

A colony-wide survey to provide information on which control policies can be based is in progress, and a trial to determine possible resistant varieties has been laid down. Until such varieties are available, the elimination of infected areas and the adoption of measures to minimize dissemination should hold the disease in check.

\section{P. B. HUtchinson W. T. DAIE}

Imperial College of Tropical Agriculture, Trinidad, B.W.I.

Feb. 12

${ }^{3}$ See Arruda, S. C., and Amaral, J. F. do, Phytopath., 35, 135 (1945). 